\title{
A new approach to evaluate site quality for reforestation programs
}

\begin{abstract}
Foresters have long applied the principle of matching site with trees in forestry. Finding suitable sites for a tree species, or finding suitable tree species for a given site, have typically been achieved through comprehensive understanding of plant-soil relationships by observations or correlation analyses. A recent study offered an eyeopening approach of using site calcium supply potentials to evaluate the site quality for tree plantations. When tree growth demand for calcium equals to site calcium supply, the site is then suitable for the tree species. Deviation from this calcium demandsupply balance leads to reduced suitability for the tree species. This "matching calcium with tree" approach reflects the simple facts that trees need carbon hydrates to build cells and calcium to glue these cells together, and that calcium is immobile between live cells. The new approach has apparent advantages of being simple in practice and using the same variables to evaluate site quality among locations, researchers, and temporal scales.
\end{abstract}

Keywords: Evapotranspiration potentials, plant transpiration, reforestation, site quality, soil calcium, sylviculture, tree plantations
Volume 2 Issue 4 - 2018

\author{
Wei Huang,' Xiaoming Zou',2 \\ 'Department of Environmental Sciences, University of Puerto \\ Rico, USA \\ ${ }^{2}$ College of Biology and the Environment, Nanjing Forestry \\ University, China
}

\begin{abstract}
Correspondence: Xiaoming Zou, College of Biology and the Environment, Nanjing Forestry University, Nanjing, Jiangsu 210037, China, Tel + I 78776400 00, Emails xzou201 I@gmail.
\end{abstract} com,xzou2015@163.com

Received: July 07, 2018 | Published: July 16, 2018

\section{Introduction}

Matching site with trees is a key principle in reforestation programs for centuries. ${ }^{1,2}$ The conventional approach to evaluate site quality was typically achieved through correlation analyses between tree growth and environmental factors, including indices of climate, soil type, soil fertility, and topography. ${ }^{3,4}$ This empirical approach works fine, but lacks the fundamental understanding of causal relationships between tree performance and its environment, and it brings inconsistency in key factors determining site quality among tree species, between sites, and among evaluators.

A recent advancement was made to evaluate site quality for tree plantation using site calcium supply potential as a single factor. ${ }^{5}$ When site calcium supply potential matches calcium need for tree growth, the site was scored as the top quality site for particular tree species, otherwise the site was rated as secondary or low quality for the tree species. This approach is not in conflict with our conventional understanding, and the tree growth is influenced by multiple environmental factors because a site calcium supply potential was calculated by multiplying soil water extractable $\mathrm{Ca}$ with actual transpiration, which integrates all physical environmental factors, including climate, soil parent materials, topography, and soil development stages, and biological factors. For example, soil water extractable $\mathrm{Ca}$ is determined by soil parent materials, topographical positions, soil developmental stages, plant litter dispersal, and harvesting, whereas actual transpiration is largely determined by climate and soil water holding capacity and varies with tree species.

\section{Principles behind "matching calcium with trees"}

Plant growth requires together the availability of light, $\mathrm{CO}_{2}$, water, and nutrients. For a given management area typically $<10 \mathrm{~km}^{2}$, light and $\mathrm{CO}_{2}$ are relatively invariant, therefore, site quality is largely determined by water and nutrient availability. Typically, plant use $<1 \%$ water for growth and the majority of plant water was used for transpiration. ${ }^{6}$ The process for plant photosynthesis is coupled with the process for water transpiration, both processes require stomatal cell opening. Thus, plant growth is also coupled with its water transpiration. The evaluation of plant annual water transpiration is extremely difficult, if not impossible, to estimate in the field, and is represented in practice by actual water transpiration potential. ${ }^{7}$ It is well known that actual water transpiration is the single best predictor of forest productivity and plant distribution. ${ }^{8,9}$ It is rational to think that plant growth is determined by nutrient supply associated with transpiration.

Liebig's Minimum Law states that plant growth is limited by a single relatively scarcest nutrient. ${ }^{10}$ Considering both actual water transpiration as the single best predictor for plant growth and the single scariest nutrient limiting plant growth, one can logically link the process of water transpiration with plant passive nutrient uptake. Among plant essential macro nutrients, nitrate, calcium, magnesium and sulfur typically have passive uptake pathway, whereas ammonium, potassium, and phosphorus are typically recognized to have an active uptake pathway. ${ }^{11}$ Micro essential nutrients rarely, although possible, limit the plant growth. ${ }^{12}$ Therefore, the scariest limiting nutrients are most likely among nitrate, calcium, magnesium, or sulfur. Calcium stands out for its $100 \%$ passive uptake pathway and its sensitivity affecting plant growth because (1) calcium cannot be relocated from old tissue to young tissue through live cells when it becomes limiting, ${ }^{13}$ and (2) overdose supply of calcium leads to the closure of stomatal cells. ${ }^{14,15}$ All other macro nutrients with passive uptake pathways do not have these properties, and variations in its availability accordingly are not as sensitive as calcium in affecting tree growth. Therefore, calcium supply potential is likely the best predictor of plant performance for a given site to reflect site quality, but it does not necessarily mean that calcium is the limiting nutrient for plant growth.

\section{How to evaluate "matching calcium with trees"?}

The principle under "matching calcium with trees" is that a tree 
grows the best when its growth demand for calcium matches calcium supply-insufficient or overdose of calcium supply will reduce tree growth. Growth demand for calcium is the product of annual biomass growth $(\mathrm{B})$ and tissue mean calcium concentration $\left(\mathrm{Bc}_{\mathrm{a}}\right)$, whereas site calcium supply is the product of annual transpiration $\left(\mathrm{E}_{\mathrm{t}}\right)$ and mean calcium concentration in soil solution $\left(\mathrm{Sc}_{\mathrm{a}}\right)$, that is:

$$
B \times B c_{a}=E_{t} \times S c_{a}
$$

Assuming tissue mean calcium concentration is proportional to a tissue organ (e.g., leaf, twig, or trunk) calcium concentration $\left(\mathrm{B}^{\prime} \mathrm{c}_{\mathrm{a}}\right)$ and tree annual transpiration is proportional to annual actual evapotranspiration (E), equation (1) then becomes:

$$
B=E \times S c_{a} / B^{\prime} c_{a}
$$

$\mathrm{E}$ in $\mathrm{mm}$ can be calculated using Lieth-Box model ${ }^{16}$ $E=1.05 P /\left[1+\left(1+1.05 P / E_{p}\right)^{2}\right]^{-1 / 2}$, where $P$ is annual precipitation $(\mathrm{mm}), E_{p}$ is annual potential evapotranspiration and equals to $3000+25 \mathrm{t}+0.05 \mathrm{t}^{3}$, when water is not limiting during growing season, where $\mathrm{t}$ is annual mean temperature $\left({ }^{\circ} \mathrm{C}\right)$; In areas where drought stress is apparent during growing season, $E p=0.533 D_{0}(10 t / J)^{\alpha}$; where $D_{0}$ is the annual mean daily sunshine hours, $t$ is annual mean temperature averaged from monthly mean temperature $T_{m}(m=1,2 \ldots, 12), J=\Sigma\left(T_{m} / 5\right)^{1.514}$, and

$$
\alpha=6.75 \times 10^{-7} \times J^{3}-7.71 \times 10^{-5} \times J^{2}+1.79 \times 10^{-2} \times J+0.49 .
$$

Next, calculate $B_{i, j}$ using equation (2) where $i$ is tree species 1,2 , $\ldots$ and $\mathrm{j}$ is site $1,2, \ldots$ To choose sites for a given tree species, one compares $B_{i, j}$ values and the top fraction (e.g., 20\%) can be classified as the highest quality site for the tree species, and so on. To choose tree species for a given site, one compares, $B_{i, j}$ values and the best performers are selected as plantation species for a given site.

\section{A case study in liaoning of China}

Zhou \& $\mathrm{Zou}^{5}$ made a case study to evaluate site quality for the tree species Liaodong oak (Quercus liaotungensis Koidz) using the above described approach. They obtained climate data from weather stations in each county, took mineral soil samples of 0-20 cm along with forest inventory carried out in 2015 at a grid points of $4 \times 6$ $\mathrm{km}$ across the entire Liaoning province of China, collected live leaf samples of the Liaodong oak when available. Soil $\mathrm{Ca}$ was extracted with deionized water. Leaf $\mathrm{Ca}$ was the total $\mathrm{Ca}$ concentration in leaves. They calculated E values using the Lieth-Box model, ${ }^{15}$ interpolated E values to each grid point using GS + Version 9.0 (Gamma 194 Design Software 2008), and obtained B values using equation (2). These B values correlated well with the measured annual biomass growth from the forestry inventory data with $R^{2}$ reached 0.41 and $P<$ 0.01 . They then made a site classification map with arbitrary classes: class I as $>80 \%$ of the maximum B value, class II $60 \%-80 \%$, class III $40 \%-60 \%$, class IV $20 \%-40 \%$, and class $\mathrm{V}<20 \%$. They made final recommendation for suitable plantation sites of the Liaodong oak as site classes I and II.

Apparently, one case study is not sufficient to evaluate the suitability of using calcium supply potentials to evaluate site quality as expressed in equation (2) for the development of reforestation programs. However, this "matching calcium with trees" approach provides a new angle for evaluating site quality that was based on mechanistic understanding of tree performance and nutrient supply levels. This "matching calcium with trees" approach is simple, quantitative, and invariant with site, human, or temporal dates. It is worthy to be further tested in other sites and by other researchers and forest managers.

\section{Acknowledgements}

Support for this study was provided by a joint venture agreement (14-JV-11120101-018) from IITF to UPR.

\section{Conflict of interest}

Author declares there is no conflict of interest.

\section{References}

1. Cotta H. Systematische anleitung zur taxation der waldungen (systematic Instructions for taxation of forests). Germany: AGRIS; 1804.

2. Van Breugel M, Hall JS, Craven DJ, et al. Early growth and survival of 49 tropical tree species across sites differing in soil fertility and rainfall in Panama. Forest Ecology and Management. 2011;261(10):1580-1589.

3. Carmean WH. Forest site quality evaluation in the United States. Advances in Agronomy. 1975;27:209-269.

4. Barnes BV, Pregitzer KS, Spies TA, et al. Ecological forest site classification. Journal of Forestry. 1982;80(8):493-498.

5. Zhou Y, Zou X. From matching site with trees towards matching calcium with trees. Journal of Nanjing Forestry University (Natural Sciences Edition). 2017;41(2):1-8.

6. Sinha RK. Modern plant physiology. USA: CRC Press; 2004.

7. Lai CT, Katul G. The dynamic role of root-water uptake in coupling potential to actual transpiration. Advances in Water Resources. 2000;23(4):427-439.

8. Stephenson NL. Climatic control of vegetation distribution: the role of the water balance. The American Naturalist. 1990;135(5):649-670.

9. Svenning JC. Deterministic Plio-Pleistocene extinctions in the European cool-temperate tree flora. Ecology Letters. 2003;6(7):646-653.

10. Gorban AN, Pokidysheva LI, Smirnova EV, et al. Law of the minimum paradoxes. Bulletin of mathematical biology. 2011;73(9):2013-2044.

11. Bowling D, Macklon A, Spanswick R. Active and passive transport of the major nutrient ions across the root of Ricinus communis. Journal of Experimental Botany. 1966;17(2):410-416.

12. Yu Q, Rengel Z. Micronutrient deficiency influences plant growth and activities of superoxide dismutases in narrow-leafed lupins. Annals of Botany. 1999;83(2):175-182.

13. Clarkson DT. Calcium transport between tissues and its distribution in the plant. Plant, Cell \& Environment. 1984;7(6):449-456.

14. McLaughlin S, Wimmer R. Tansley Review No. 104 Calcium physiology and terrestrial ecosystem processes. The New phytologist. 1999:142(3):373-417.

15. Allen GJ, Chu SP, Harrington CL, et al. A defined range of guard cell calcium oscillation parameters encodes stomatal movements. Nature. 2001;411:1053-1057.

16. Sharpe DM. Methods of assessing the primary production of regions: Primary productivity of the biosphere. Germany: Springer; 1975. p. 147166. 